Peer-Reviewed Article

ISSN: 2162-3104 Print/ ISSN: 2166-3750 Online

Volume 5, Issue 3 (2015), pp. 271-284

(C) Journal of International Students

http://jistudents.org/

\title{
International Students in Western Developed Countries: History, Challenges, and Prospects
}

\author{
Emmanuel E. Akanwa (Doctoral Student) \\ Central Michigan University (USA)
}

\begin{abstract}
Many scholars have described the various challenges international students face in Western developed countries including the United States, the United Kingdom, and Australia. Some of the challenges include differences in culture, language barriers, adjustment problems, medical concerns, pedagogical challenges, housing issues, lack of support services, and financial difficulty. This paper explores some challenges of international students and implicates the need for host universities to provide more resources and support services towards meeting international students' academic and social needs. Aside from exploring the challenges, conflicts, and contradictions to the international student experience, and their implications to academic performance, the paper presents recommendations and suggestions to host universities on how to meet international students' varying academic and social needs.
\end{abstract}

Keywords: international students, adjustment issues, cultural variation, host countries, challenges, learning experience, developed countries, degree completion

Various scholars have explored the academic and social challenges international students face in the U.S., the U.K., and Australia (Alden, Ryder, Paulhus, \& Dere, 2013; Li, Chen, \& Duanmu, 2010; Ruble \& Zhang, 2013). Of the various studies on international students' adjustment to education and life in the U.S., the U.K., and Australia, a common theme which is always present is the difficulty experienced by international students as they pursue their education in foreign countries. Research on international students' experiences in Western developed countries is full of studies describing the difficulty faced by international students in those countries. Given that international students encounter social, cultural, financial, medical, adjustment, and academic challenges which invariably impact their educational performance, a responsibility lies with the U.S., the U.K., and Australian higher educational institutions to ensure that adequate provision of resources are provided to meet international students' diverse academic and social needs.

The call to address the social and academic needs of international students aligns with Stoll, Bolam, McMahon, Wallace, and Thomas' (2006) assertion that, "to be successful in a changing and increasingly complex world, it is suggested that whole school communities need to 
work and learn together to take charge of change, finding the best ways to enhance young people's learning" (p. 222). In order to meet the academic and social needs of international students, host universities must be engaged in a collaborative effort to ensure students' success by implementing strategies and policies that facilitate a richly rewarding academic and social experience. To that end, educational institutions in the U.S., the U.K, and Australia must be committed to providing an enabling environment that is capable of meeting international students' needs, as well as equipping international students with relevant social and academic skills. Similarly, international students must be actively committed to studies and campus activities in order to gain the best their universities have to offer.

\section{Literature Review}

\section{Historical Context to International Student Contact}

In International Students in American Colleges and Universities: A History, Bevis and Lucas (2007) stated that international student contact can be traced to the second and fifth centuries. They observed that "as early as the second century BCE, the attendance rolls of the city-state's schools of philosophy and rhetoric attest to the admission of foreigners in comparatively large numbers" (Bevis \& Lucas, 2007, p. 15). In the fifth century, Sophists (teachers of wisdom) arrived in Athens, and were accompanied by protégés - youths from distant regions who traveled with their masters as they moved from one city to another in search of new students (Bevis \& Lucas, 2007).

Furthermore, Bevis and Lucas (2007) referred to Socrates' statement about foreigners who followed Protagoras from city to city in order to learn of his wisdom and philosophy. They observed that "Most of Protagoras' followers seem to be foreigners; for these the Sophist brings with him from the various cities . . charming them . . . with his voice, and they, the charmed, follow where the voice leads" (p.14-15). From the literature, foreign students migrated from city to city in Athens and beyond as they sought to learn from the wisdom of ancient Greek philosophers. More so, it is arguable from the above historical standpoint that international student mobility started between the second and fifth centuries in Athens.

However, international student contact on record in the United States did not start until the late $18^{\text {th }}$ century. The American immigration laws did not make the U.S. institutions a choice-destination for international students as "the growing concern about the number of immigrants entering the country resulted in a handful of individual states passing restrictive immigration laws" (Bevis \& Lucas, 2007, p. 56). As such, the United States did not witness tremendous growth in foreign student population in the early phase of American higher education. To further complicate the scenario, Bevis and Lucas (2007) observed that the Chinese Exclusion Act of 1882 "prevented any Chinese without family already in the U.S. from entering the country, thus effectively halting almost all new immigration from China" (p. 57). Similarly, Bevis and Lucas (2007) argued that the Scott Act of 1888 "prohibited immigration of virtually all Chinese, including those who had gone back to China to visit and had planned to return" (p. 57). Consequently, "the loss of foreign students was one of many repercussions of the new restrictions" (Bevis \& Lucas, 2007, p. 57).

The above regulations affected international students' choice of the U.S. for higher education, and this invariably, opened a large international student market for other developed countries with less strict immigration laws. However, the current U.S. policy on immigration is geared towards making immigration and visa procedures easier and more transparent (Becker \& 
Kolster, 2012). Consequently, the U.S. immigration policy has improved as qualified students are registered through the Student and Exchange Visitor Program (SEVIS) system and granted student visas for the duration of study (Becker \& Kolster, 2012). With the improvement of the student visa policy, and the perceived quality of the American higher education, the U.S. has maintained its position as the number one host country for international students; and it "will remain one of the most important study destinations worldwide for some time to come" (Becker \& Kolster, 2012, p. 37)

Historically, students have sought educational opportunities in countries other than their own with the intention of getting advanced education that is capable of making them exceptional among their peers. This point is reinforced by Hegarty's (2014) observation that international students study in other countries "for the simple reason that they feel they can get a better education abroad which will differentiate them from their peers upon returning home" (p. 228). In view of this assertion, universities have for centuries been interested in extending educational opportunities to international students who meet their admission and tuition requirements, among other criteria. With regard to international students' quest for foreign education, universities in developed countries are perceived as invaluable international institutions where students go to gain desired education and training. Thus, the singular quest for advanced education resulted in student migrations as early as the Middle Ages when students migrated from various regions to attend medieval institutions such as Bologna and Paris in the 12th century (Altbach, 1998; Guruz, 2011; Haskins, 1957, as cited in Garcia \&Villarreal, 2014, p. 127).

As international institutions, right from antiquity, universities opened their doors to international students from various countries of the world. The presence of universities increases migration of students in search of knowledge and education. This assertion aligns with Bevis and Lucas' (2007) observation that, "whenever a center of scholarship and learning arose in ancient times, the gathering of scholars it drew invariably included 'foreigners' - that is, students not native to the immediate local area" (p. 13). Hence, ancient universities embraced international students and provided them with opportunities for learning and development. Since then, international students have remained an important aspect of contemporary higher education.

According to Guru (2011) "a look at the nations in the two oldest universities, Bologna and Paris, clearly shows the international character of the medieval university and the degree of international mobility that existed centuries ago" (p. 153). As such, it was characteristic of the two oldest universities to accept and admit international students. In the same manner, international education increased student mobility. Fortunately, this tradition is sustained by contemporary universities in the sense that international students have come to represent an important demographic in higher education (Becker \& Kolster, 2012).

Furthermore, Germany had a record of international student migration in the $19^{\text {th }}$ century. German universities opened their doors in the $19^{\text {th }}$ century for a teeming population of students in search of scholarship and research (Altbach, 1998; Veysey, 1965). German university education was highly prestigious and most scholars that were educated in Germany obtained faculty positions in major American universities (Altbach, 1998; Thelin, 2004; Veysey, 1965). Thus, given the high quality of university education in Germany in the $19^{\text {th }}$ century, it was natural for international scholars to migrate to Germany for advanced education. In that regard, Garcia and Villarreal (2014) characterized the value of a degree from Germany and argued that a doctorate degree from Berlin was considered highly prestigious despite the fact that the cost of completion was lower than at U.S. institutions. 
The above literature described international student flow to universities in Bologna (Italy), Paris, and Germany and how the trend has continued over the centuries to the present time. Currently, the tide of international student mobility has shifted to the U.S., the U.K., Australia, and Canada, among other destinations. Given the current status of the United States as the number one country for receiving the most international students, it deserves critical attention in this study. The contemporary prominence and fame enjoyed by American universities could as well be attributed to the Second World War, when the U.S. government and policy makers began to fund scientific research projects at universities (Graham and Diamond, 1997, as cited in Garcia and Villarreal, 2014). After World War II, the United States invested a large amount of money in research and scholarship, and subsequently, these research funds attracted international scholars to U.S. institutions of higher learning.

Similarly, in his appraisal of the federal research funds, Thelin (2004) noted that the first wave of post-World War II federal research funding flattened off in the late 1950s, and was replenished by a new financial support incentive in 1957. This incentive was the congressional response to the Soviet Union's launching of the Sputnik satellite which made more funds readily available for scientists and researchers. As a result of World War II and the Soviet Union's launch of a satellite, federal funds became widely available for researchers from around the world to investigate and research various technological and scientific advances that were capable of making the United States remain competitive in the face of global challenges. America's global position in research and invention in the 1950s was fundamental to the influx of international students to the U.S. institutions of higher education. Additionally, on the importance of federal funding and its implication to the U.S. higher education, Garcia and Villarreal (2014) noted that with substantial federal funding and the ability to attract preeminent scholars from around the world, U.S. universities became the envy of the world. Consequently, there was a shift in the number of students that no longer yearned to go to Europe but remained in the United States for their higher education.

American higher education has remained a center-piece for international students from around the world. However, although the U.S. higher education institutions attract international scholars from around the world, it has its share of the challenges and difficulty that characterize international students' experiences in the U.K, Australia, and elsewhere in the world. The next section explores various themes emerging from the international student experiences in the U.S., the U.K., and Australia as represented in the literature.

\section{Themes and Conceptual Frameworks}

\section{Cultural Variation and International Students' Academic Experience}

Rienties, Nanclares, Jindal-Snape, and Alcott (2013) observed that international students from the same cultural background tend to work well with each other, as compared to working with those from host countries. Their study showed that over a period of 14 weeks, international students were able to bond well with domestic students as well. However, the higher projection is that international students worked better with those who share their kind of experiences and cultures. One's knowledge and cultural values may influence how students learn and engage with instructional content, as well as how they relate with others. Thus, "instructional design of team work has a strong influence on how international and home students work and learn together" (Rienties, et al., 2013, p. 332). While students are naturally, but unconsciously, attracted to those who share similarities with them, an instructional design that incorporates team work could boost 
cooperation and influence international students' relationship with domestic students. Rienties, et al. (2013) described international students' tendency to get along with students who share a similar culture with them; however, they highlighted how invaluable it is for classroom instructions to incorporate group work that brings together students from different backgrounds.

Facilitating a diverse academic environment where international students could interact with fellow international students as well as domestic students is crucial to academic success. Students are attracted to those with similar passions, experiences, interests, values, and those interested to learn about others (Rienties, et al., 2013). Therefore, emphasizing diversity and assigning group work to students could improve international students' academic performance. In the same manner, international students must take advantage of the rich interactions provided by their domestic counterparts in the classrooms. The benefits of engaging in meaningful classroom discussions and sharing of ideas and experiences should be utilized by international students as they strive to gain the best from their classmates' experiences, perspectives, and cultures.

For Western developed universities to remain competitive and attract more international students, it is important that university administrators and professors put more effort into understanding how cultural factors influence international students. While culture has been defined differently by various scholars to reflect the collection of values, beliefs, behaviors, customs, and attitudes that distinguish a society (Fan, 2000), it remains central to how students approach learning. Culture includes factors such as "acquired knowledge, learned patterns of behaviour, attitudes, values, expectations, rituals and rules, a sense of identify and of history" (Webb \& Read 2000, p.1). Since culture characterizes an individual's identity, understanding how to influence those identities and directing learning experiences to align with international students' learning styles will most definitely enhance learning and improve academic performance.

The discourse on cultural influences on international students' learning presents a responsibility to universities and colleges to train their staff and faculty to learn best practices in the education of international students. On the question of best practices and challenges faced in meeting international students' academic needs, Li, Chen, and Duanmu (2010) contended that with increasing international student populations, "how to improve international students' study experience is a strategic issue faced by most universities given the growing competition between each other" (p. 390). Their study emphasized the importance of meeting international students' needs, especially as higher education becomes more competitive in the present century. Working with international students can be challenging, however, getting the appropriate skill level, knowledge base, orientation, and training that could help university administrators, faculty and staff to better service their students must be of strategic importance. Equally, international students have a responsibility to develop their full potentials by taking advantage of the many opportunities and resources available to them at their host institutions of learning. As such, the task of meeting international students' academic and social needs is a complementary one that involves taking responsibility and actions by administrators and students as well.

$\mathrm{Li}$, et al. (2010) compared Chinese students with other international students in terms of learning behavior and key predictors of academic achievement. Central to their findings is the emphasis of institutions to increase "the awareness of the cultural diversity in the higher education settings to better support international students' learning experiences and gain competitiveness in the international higher education market" (p. 390). As international student populations keep increasing, higher education leaders must strive to provide all necessary 
support services including promoting cross-cultural competence among professors and administrators to relate well with international students, while meeting their academic and social needs. Li, et al. (2010) asserted that the increasing population of international students in higher education institutions has stimulated the interest in cross-cultural studies in relation to student learning.

While awareness of cultural diversity and its impact on international students' performance are critical components influencing learning and academic success, it is equally important to underscore the fact that a student's prior academic background could serve as a necessary predictor of academic performance. McKenzie and Schweitzer (2001) grouped performance predictors into four categories: academic, psychosocial, cognitive, and demographic. On academic factors, they noted that a student's prior academic achievement is a vital performance predictor of the student's future academic performance at higher levels of study. Therefore, an international student's prior academic performance and experiences could greatly influence academic performance in a foreign university.

McKenzie, Gow, and Schweitzer's (2004) study further reinforced the point that past academic achievement plays a huge role in predicting students' learning outcomes and performance. While adjustment to university life could be a challenge to international students, those with a prior achievement record may not find it difficult to cope with international higher education. It is however, necessary to note that prior academic achievement does not always result in successful academic performance. As such, Burch (2008) found that most of his international post graduate students did not perform well in their first year although their "priorlearning strategies based on reproduction [led them to assume] that these strategies will work in the Australian environment" (p. 19). Thus, although prior knowledge is a necessary predictor, it is dictated by pedagogy, content, and environment. Consequently, it is possible for an intelligent student to suffer academically in a different educational environment such as the U.S., the U.K., or Australia.

Moreover, student engagement is a critical factor in considering academic performance. Chan and Ryan (2013) stated that "student engagement, including engagement in learning, is recognized as a critical factor in student retention and progress" (p. 172). Given that retention is directly related to progress, it has a corresponding relationship to degree completion. To that end, when students are engaged in their academic work, chances are that they will have better academic performance. Student engagement refers to "involvement with activities and conditions likely to generate high-quality learning" (ACER, 2010, p. 3). While university leaders improve policies and services to provide a favorable learning environment for international students, international students on their part must get involved with activities on campus, including engagement with instructional content, behaviors that improve learning, cultural/cross-cultural programs, student organizations, learning groups, and other events that characterize their experiences on campus.

\section{Language Barriers to International Students' Learning}

Studies indicate that proficiency with English language speaking and writing skills are vital to international students' academic performance. Li, et al. (2010) observed that, "for those international students whose first language is not English, their proficiency in English plays a crucial role in successfully completing their studies in an English-speaking learning environment" (p. 4). Although students whose first language is not English are advised to take the Test of English as Foreign Language (TOEFL) prior to admission into most Western 
universities, taking and passing TOEFL does not always translate into proficiency in the English language. Therefore, upon admission to institutions of higher learning, international students are advised to take advantage of every English language learning opportunity in order to improve their speaking, listening, reading, and writing skills. On their part, university professors need to encourage and emphasize the development of English language skills by incorporating some language-focused assignments into their curriculum, and be able to provide feedback on students' language use.

English language proficiency is important not only for academic purposes, but also for the social adjustment of international students (Andrade, 2006). While most studies focus on English for academic purposes, it is important to state that knowledge of the English language helps students in building social relationships as well. Thus, international students may improve their English by interacting with other students even when their English is not well formed. Yeh and Inose (2003) observed that the English language may be the single greatest barrier experienced by international students as it affects their academic performance, and impacts their ability to socially engage with other students (as cited in Sherry, Thomas, \& Chui, 2010). In the same manner, instructional strategies that emphasize classroom participation may prove challenging to international students whose prior educational experience was passive, and one that did not require students' active involvement with knowledge construction and sense-making in the classroom. Thus, the use of oral English for classroom participation may be a challenge to those international students who are from an educational system where reading skills were emphasized at the expense of conversational skills (Sawir, 2005).

Similarly, Cheng and Erben (2012) argued that Chinese students generally face language anxiety when it comes to written and spoken usage of English language in the U.S. institutions of higher education. In their study, Cheng and Erben (2012) stated that Chinese students who gain language competency are those that have stayed longer in the U.S as well as those studying arts related courses. Their study considered length of stay, course of study, and gender as some determining factors to language competency. From the study, "results showed that students who stayed longer and were in art-related majors had the lowest anxiety. What [was] also revealed from this study was that gender and acculturation did play some roles on language anxiety levels" (Cheng and Erben, 2012, p. 477). While their study revealed that gender plays a role in language competency, they affirmed that Chinese students, like some other international students, have the problem of English language as a barrier to their education in Western developed countries.

According to Kuo's (2011) study, language is a central hindrance to international students' learning in the United States. Kuo's description of the language problem focused on "listening comprehension and oral proficiency" (p. 39) as the greatest language challenges of international students. By their very nature, listening comprehension and oral proficiency require praxis and informed action which are skills that may be developed through training and constant interaction. Therefore, training professors and staff in cross-cultural communication could help to develop international students' language skills. Kuo's (2011) study identified listening comprehension and oral proficiency as major language barriers to international students. Consequently, it is important that professors monitor their pace when teaching or interacting with international students. This is because "the pace with which an instructor delivers a lecture has obvious implications for students' ability to keep up with the presentation and maintain attention" (DeZure, Kaplan, \& Deerman, n. d., p. 3). 


\section{University Resources and their Effects on International Students}

Various resources and support services available to international students are instrumental to their success in universities and colleges. International students do not only need human resources personnel, they also need other support services capable of making their educational experiences successful, engaging, and rewarding. In their study, McFadden, MaahsFladung, and Mallett (2012) described the pivotal role of faculty and other university resources to students' educational decisions and choices. They stated that despite degree level, all students ranked faculty-student ratio as an important program characteristic. The study also revealed that students ranked both the admission process and time to degree completion as important characteristics. Similarly, McFadden, Maahs-Fladung, and Mallett's (2012) study indicated that doctoral, masters, and bachelor's degree students ranked funding as an important characteristic in their decision and choice of a university. They emphasized the need for institutional leaders to make funds available to support their education whenever the need arises The study characterized international students' need to have adequate faculty-student ratio in order for students to have access to professors whenever they have academic concerns. In the same manner, the university admission process should be a less complicated process, making it easier for international applicants to gain admission (McFadden, et al. 2012).

On the other hand, Mamiseishvili (2012) emphasized the importance of supporting the language and other needs of international students. His study portrayed why it is important for faculty and staff to be involved in international students' academic success and subsequently, in their persistence outcomes and degree completion. In addition, the integration of international students can be actualized "by incorporating more cooperative learning activities into their classes to help them develop friendships with other students" (Mamiseishvili, 2012, p. 15).

It is obvious that universities in the U.S., the U.K., and Australia need to improve their support services and resources for international students. When all needed resources and services are in place, international students stand a greater chance of having a supportive educational experience that could facilitate degree completion. The strength of Mamiseishvili's (2012) study does not only lie on his advocacy for English language programs for international students, but more on his general support of the international student course. To that end, the literature "suggests policies, services and programs to meet this population's unique needs and to assist in their academic success in the United States" (Ren \& Hagedorn, 2012, p. 135), and of course, in the U.K., Australia, and other developed countries serving as destinations for international students.

According to Roy's (2013) study on educating Chinese, Japanese, and Korean international students, several recommendations were suggested to American professors about best practices on educating these students. Roy (2013) characterized Chinese, Japanese, and Korean international students' learning challenges to include the language barrier, poor communication skills, difficulty in understanding long and complex sentence structures used by some professors, inability to grasp American slang expressions unconsciously used by some professors in class, the difficulty of working with groups on class projects, and being uncomfortable with open-ended class discussions.

The above learning barriers arise due to Chinese, Japanese, and Korean students' unique ways of learning which are different from the U. S. pedagogical strategies. Consequently, Roy (2013) stated the importance of American professors to understand best practices in teaching these students, while at the same time emphasizing the need for international students to work hard to improve on their academic, social, and adjustment skills. Roy (2013) further described 
various learning difficulties faced by international students and contended that, "these learning difficulties arise because of inability of some American professors to use discourse markers, summarize at the end of lectures, write key concepts on the blackboard, etc." (p. 10). In addition, Roy (2013) noted that by using emotional intelligence (Goleman, 1998), the creating mind (Gardner, 2007), and the respectful mind (Gardner, 2007), professors could enhance the learning experiences of international students.

Furthermore, Hegarty (2014) described the contributions of international students to the United States and contended that it must be a strategic imperative for university administrators to ensure that all the academic needs of international students are met. While emphasizing the importance of meeting students' varied needs, Hegarty (2014) stated that once international students are enrolled, efforts must be made to ensure that they are well received and assimilated quickly into college life to improve retention and ensure adequate classroom performance. He emphasized international students' financial contribution to universities and underscored the importance of addressing their concerns. Thus, the needs of international students must be addressed because failure to recognize or plan without this student population in mind may lead to diminished funding for colleges and program failures in certain academic disciplines (Hegarty, 2014).

International students are an essential part of the higher education system. As such, higher education institution leaders must be committed to meeting their needs and expectations, especially given the rising competition in the international education market. The challenge of meeting international students' academic, adjustment, and social needs is crucial and must attract policy and strategic attention in the U.S., the U.K., and Australian higher education institutions.

\section{Social Adjustment and Building Relationships: Influence on International Students' Performance}

Ryder, Alden, Paulhus, and Dere (2013) evaluated the effectiveness of acculturation as a predictor of interpersonal adjustment. They argued "social adjustment, although critical to the acculturation process, has been relatively neglected" (p. 502). While the study described the effects of acculturation on international students in Western developed countries, it supports the literature on interpersonal adjustment as a critical factor to academic and social adjustment. Since adjustment is one of the practical challenges international students face, Ryder, Alden, Paulhus, and Dere's (2013) study stated the need for international students to learn interpersonal adjustment skills that could help them adjust to academic and social life in their new educational environment, and by extension, succeed in their studies. As such, international students have a significant part to play in order to ensure that they adapt to their environment. To that end, international students must not depend on host institutions for development of interpersonal adjustment skills.

On the contrary, Montgomery and McDowell, (2009) criticized the perception that international students in the U.K. are disadvantaged because of separation from their culture and methods of education. Montgomery and McDowell (2009) argued that despite cultural differences, international students in the U.K. (and perhaps elsewhere) have developed strategies that help them to form relationships with fellow international students. To a great extent therefore, international students in the U.K. do not need to depend on domestic students for academic success. Thus, central to Montgomery and McDowell's (2009) study is the argument that international students could succeed in their education whether or not they relate to, or associate with the U.K. students. While their research described international students' 
challenges in a foreign environment, they argued that international students are able to overcome some of their adjustment and cultural challenges by forming a bond of relationship with fellow international students. Consequently, international students serve as sources of strength and encouragement to each other. This form of relationship between international students is important as a survival strategy; it definitely will improve if universities could help strengthen the relationships between international students from different countries and cultures through a variety of programs and cross-cultural interactions.

In Why Can't We Be Friends? William and Johnson (2011) investigated the relationship between American and international students, and studied how this relationship impacts students' learning. Central to their study is the proposition that international students who made friends with American students have the advantage of overcoming "acculturative stress" and also perform better in their education than those who do not maintain such relationships. Although it is beneficial to have social relationships with the host community, William and Johnson's (2011) study explored the difficulties international students encounter in trying to be friends with American students. They argued that although studies suggest friendships with domestic students are important for a successful experience, forming friendships with American students is challenging and rare (William \& Johnson, 2011). Consequently, they concluded that "difficulties establishing friendships are exacerbated when the context of adjustment is marked by prejudicial attitudes or a history of problematic intercultural relations" (William \& Johnson, 2011, p. 41)

Based on the preceding literature, part of the problems international students encounter include the forming of relationships and friendships with domestic students. There is also the problem of interpersonal adjustment, as well as the perceived likelihood of international students to form a bond among themselves instead of interacting and relating with domestic students. With these factors in mind, enabling a more diverse campus and giving domestic students orientation on the need to make friends with international students may ease some of the social, adjustment, and relationship challenges that could impact the academic success of international students. International students are encouraged to take advantage of every opportunity to interact with and become familiar with the host students. Moreover, friendly interaction between international and domestic students is beneficial to both parties. Domestic students need to develop multicultural skills and diversity awareness as invaluable skills for today's global economy, while international students could learn language, cultural, and communication skills from domestic students. Above all, both domestic and international students have much to learn from the diverse perspectives of each other as the society leans towards improving diversity and multicultural competency. Consequently, university administrators have an ever-increasing responsibility to meet the various needs of international students. In the same manner, international students must effectively utilize all opportunities that their institutions provide for them in order to improve their academic and social skills.

\section{Recommendations and Suggestions to Administrators and Faculty}

Contemporary higher education institutions are invested in students' enrollment, retention, and graduation. Currently, the international student market is facing a huge competition as universities and colleges are committing resources and efforts to attract international students to their educational institutions (Zheng, 2014; Binsardi \& Ekwulugo, 2003; British Council, 2011; Hemsley-Brown \& Goonawardana, 2007). However, international students seem to be left on their own upon enrollment as they have to navigate the complex and challenging educational and 
cultural landscapes of their host universities with little or limited support services. As challenges to international students intensify, university administrators and faculty must review institutional support services for international students by ensuring that they receive all necessary support that could bolster academic success. With the plethora of challenges facing international students in the U.S., the U.K., and Australian universities, the following recommendations are critical if these universities are to remain active and competitive in attracting and retaining international students.

First, administrators and faculty need to understand the differences and uniqueness of international students as a population that is entirely different from domestic students. An understanding of the differences that characterize this student population should be reflected in the ways professors and administrators relate to and work with international students. Thus, when faculty members understand international students' cultural differences, it will help them to adopt classroom practices, which facilitate international students' adjustment into the new educational environment. Above all, as administrators and faculty learn about the cultural differences that exist among international students, it will not only inform how they teach or mentor international students, but it will also demonstrate their sense of cultural sensitivity and diversity.

Language is another major barrier to international students' learning, especially, those from non-English speaking countries. In view of this, university administrators and faculty should provide international students with additional opportunities to develop their English language skills, such as speaking, listening, reading, and writing. This could be done by organizing English language workshops, writing seminars, having informal conversation partners, and integrating more English speaking and writing assignments in course syllabi. Faculty members are the most valuable resources for international students. As the most valuable resources, faculty members should ensure they give international students additional attention and support by encouraging them to ask questions, take advantage of office hours, submit multiple drafts for instructor comments, pair international students with native speakers in class projects or group work, and also have regular informal conversations with them in order to build a good teacher-student relationship.

Moreover, administrators and faculty can help international students adjust to campus life and culture by integrating them in campus activities. International students are passionate about events around campus but in most cases they do not get involved either because they perceive such events to be for domestic students only, or because they were not aware of the event. To that end, university leaders need to help international students adjust to the university culture and climate by encouraging them to participate in volunteer services, campus tours, cross-cultural events, and all other events on campus. Additionally, international students should be informed of the various support services on campus for their use and benefit. They should be informed of funding options for them to present their research at conferences, as well as opportunities for them to apply for scholarships and awards. In most cases, international students do not know what opportunities exist for them outside the classroom.

Above all, university administrators and faculty members need to start asking the questions: what is the economic implication of a Western education? What is the perceived value of a Western degree? With the increasing cost of higher education, especially, for international students, these questions are becoming more crucial than ever before (Zumeta, n. d.; Bridgestock, 2012). As such, learning experiences provided by instructors should be of high quality, as well as other services provided by educational institutions. Arguably, the quality of 
one's education is a determining factor for the type of employment one could get upon graduation. Perhaps, the actual value of a Western education lies in the hope that upon graduation, international graduates could become successfully employed and self-sustained. Consequently, it will be of great advantage to international students if upon graduation they are provided with employment opportunities to further strengthen their skills and knowledge base.

\section{Conclusion}

The themes examined in this paper are: historical perspectives on international student contact, cultural differences, language barriers, university resources and their effects on students' learning, and the influence of social adjustment and relationship building on international students' academic performance. The paper explored the various challenges international students face in the U.S., the U.K., and Australia and implicated the need for university administrators and faculty to provide more resources and support services towards meeting international students' academic and social needs. In addition, the paper emphasized the need for international students to take advantage of all opportunities provided by their host institutions in order to improve themselves academically, socially, and otherwise. Aside from exploring the challenges, conflicts, and contradictions to the international student experience, and their implications to academic performance and degree completion, the paper presented some recommendations on how to meet the varying academic and social needs of international students in the U.S., the U.K., and Australia.

\section{REFERENCES}

Andrade, M. (2006). International students in English-speaking universities: Adjustment factors. Journal of Research in International Education, 5(2), 131-154.

ACER (2010). Doing more for learning: Enhancing engagement and outcomes. Australasian Survey of Student Engagement. ACER, Victoria, Australia.

Altbach, P. G. (1998). Comparative higher education: Knowledge, the university, and development. Greenwich, CT: Ablex Publishing.

Burch, T. (2008). Teaching and learning accounting with overseas students. People and Place, $16(1), 12-20$

Bridgestock, L. (2012). How much does it cost to study in the US? Retrieved from http://www.topuniversities.com/student-info/student-finance/how-much-does-it-coststudy-us

Bevis, T. B., \& Lucas, C. J. (2007). International students in American colleges and universities: A history. New York, NY: Palgrave Macmillan.

Becker, R., \& Kolster, R. (2012). International student recruitment: Policies and developments in selected countries. Retrieved from http://www.nuffic.nl/en/library/international-studentrecruitment.pdf

Binsardi, A., \& Ekwulugo, F. (2003). International marketing of British education: Research on the student's perception and the UK market penetration. Marketing Intelligence \& Planning, 21, 318-327.

British Council (2011). New international student trend presents fresh challenges for universities. Retrieved from: http://www.britishcouncil.org/organisation/press/new-internationalstudent-trend-presents-fresh-challenges 
Chan, H., \& Ryan, S. (2013). Challenging stereotypes: International accounting students in Australia. Journal of Modern Accounting and Auditing, 9(2), 169-182.

Cheng, R., \& Erben, A. (2012). Language anxiety experiences of Chinese graduate students at U.S. higher institutions. Journal of Studies in International Education, 16(5) 477-497.

DeZure, D., Kaplan, M., \& Deerman, M. A. (n. d.). Research on student notetaking: Implications for faculty and graduate student instructors. Retrieved from http://www.math.lsa.umich.edu/ krasny/math156_crlt.pdf

Fan, Y. (2000). A classfication of chinese culture. Cross Cultural Management, 7, 3-10.

Garcia, H.A., \& Villarreal, M.D. (2014). The "redirecting" of international students: American higher education policy hindrances and implications. Journal of International Students, 4(2), 126-136.

Guruz, K. (2011). Higher education and international student mobility in the global knowledge economy. Albany, NY: SUNY Press.

Graham, H. D., \& Diamond, N. (1997). The rise of American research universities: Elites and challengers in the postwar era. Baltimore, MD: JHU Press.

Gardner, H. (2007). Five minds for the future. Boston, MA: Harvard Business School Press Haskins, C. H. (1957). The rise of the universities. Ithaca, NY: Cornell University Press.

Hegarty, N. (2014). Where we are now -The presence and importance of international students to universities in the United States. Journal of International Students, 4(3), 223-235.

Hemsley-Brown, J., \& Goonawardana, S. (2007). Brand harmonization in the international higher education market. Journal of Business Research, 60(9), 942-948.

Kuo, Y. (2011). Language challenges faced by international graduate students in the United States. Journal of International Students, 1(2), 38-42.

Li, G., Chen, W., \& Duanmu, J. (2010). Determinants of international students' academic performance: A comparison between Chinese and other international students. Journal of Studies in International Education, 14(4), 389-405.

McKenzie, K., \& Gow, K. (2004). Exploring first-year academic achievement through structural equation modelling. Learning and Individual Differences, 14, 107-123.

McKenzie, K., \& Schweitzer, R. (2001). Who succeeds at university? Factors predicting academic performance in first year Australian university students. Higher Education Research and Development, 20, 21-33.

Montgomery, C., \& McDowell, L. (2009). Social networks and the international student experience: An international community of practice? Journal of Studies in International Education, 13(4), 455-466.

McFadden, C., Maahs-Fladung, C., \& Mallett, W. (2012). Recruiting international students to your campus. Journal of International Students, 2(2), 157-167.

Mamiseishvili, K. (2012). International student persistence in U.S. postsecondary institutions. Higher Education, 64(1), 1-17.

Ren, J., \& Hagedorn, L.S. (2012). International graduate students' academic performance: What are the influencing factors? Journal of International Students, 2(2), 135-143.

Roy, S. R. (2013). Educating Chinese, Japanese, and Korean international students: Recommendations to American professors. Journal of International Students, 3(1),10-16.

Rienties, B., Nanclares, N. H., Jindal-Snape,D., \& Alcott, P. (2013). The role of cultural background and team divisions in developing social learning relations in the classroom. Journal of Studies in International Education, 17(4), 332-353.

Ryder, A. G., Alden, L. E., Paulhus, D. L., \& Dere, J. (2013). Does acculturation predict 
interpersonal adjustment? It depends on who you talk to. International Journal of Intercultural Relations, 37(4), 502-506.

Stoll, L., Bolam, R., McMahon, A., Wallace, M. \& Thomas, S. (2006). Professional learning communities: A review of the literature. Journal of Educational Change, 7, 221-258.

Smith, P. J. and Smith S. N. (1999). Differences between Chinese and Australian students: Some implications for distance educators. Distance Education, 20, 64-80.

Sherry, M., Thomas, P., \& Chui, W. H. (2010). International students: A vulnerable student population. Higher Education, 60(1), 33-46.

Sawir, E. (2005). Language difficulties of international students in Australia: The effects of prior learning experience. International Education Journal, 6(5), 567-580.

Thelin, J. R. (2004). A history of American higher education. Baltimore, MD: JHU Press.

Veysey, L. R. (1965). The emergence of the American university. Chicago, IL: University of Chicago Press.

Webb, V., \& Read, J. (2000). The challenge of cultural heterogeneity to educational development. LAOIII Conference. Pretoria: University of Pretoria. Paper Presentation.

Williams, C. T., \& Johnson, L. R. (2011). Why can't we be friends? Multicultural attitudes and friendships with international students. International Journal of Intercultural Relations, 35(1), 41-48.

Yeh, C.J. \& Inose, M. (2003). International students' reported English fluency, social support satisfaction, and social connectedness as predictors of acculturative stress. Counseling Psychology Quarterly, 16(1), 15-28.

Zheng, P. (2014). Antecedents to international student inflows to UK higher education: A comparative analysis. Journal of Business Research, 67(2), 136-143.

Zumeta, W. (n. d.). Is higher education still worth it? Retrieved from http://www.wise-qatar.org/highereducation-financing

\section{About the Author}

EMMANUEL E. AKANWA is a Doctoral student and Graduate Research Assistant in the department of Educational Leadership at Central Michigan University, Mount Pleasant, Michigan, USA. His research focuses on studies that contribute to the frontiers of understanding the complexities of educational leadership; higher education policies; theories and practices of academic leadership; the efficacy of online vs. traditional learning; diversity and multiculturalism in American higher education. Email: akanw1ee@cmich.edu

$$
* * *
$$

